\title{
Tooth Embedded in the Upper Lip for 25 Years following Facial Trauma: A Case Report with Literature Review
}

\author{
Ekhosuehi Theophilus Agho*, Osamede Desmond Agbonifo, Sunday Olusegun Ajike and Ibrahim Musa Idris \\ Department of Dental Surgery, Ahmadu Bello University, Nigeria
}

Submission: November 08, 2020; Published: November 16, 2020

*Corresponding author: Ekhosuehi Theophilus Agho, Department of Dental Surgery, Ahmadu Bello University, Zaria, Nigeria

\begin{abstract}
Facial trauma may result in fracture, displacement or avulsion of tooth, sequel to that, tooth/ tooth fragment can be lost, aspirated, swallowed or embedded in the perioral tissue especially the lip. A 40-year-old lady presented with complaint of pain in her upper lip with a discharging sinus, there was a history of trauma to the upper anterior tooth 25 years prior to presentation. Clinical examination revealed swelling with a discharging sinus in the upper lip and the presence of a hard mass felt on palpation with area of tenderness over the upper lip. Intraoral examination revealed obliteration of the upper buccal sulcus with missing 21. Radiographs taken showed a radiopaque structure in the upper lip similar to the missing tooth. Tooth removal and sulcoplasty was done under local anaesthesia. Patient tolerated the procedure and healing was uneventful. To prevent such occurrences, comprehensive physical and radiographic evaluation of patients with facial trauma are necessary.
\end{abstract}

Keywords: Embedded tooth; Upper lip; Facial trauma

\section{Introduction}

Traumatic injuries to the oral and maxillofacial region that results in fracture, intrusion or avulsion of tooth have significant negative functional, aesthetic and psychological effects on individuals [1]. Dental trauma is usually associated with an impact force directed toward the upper incisors leading to dentoalveolar fracture and soft tissue injury [2]. Tooth/ tooth fragment can be embedded into the facial soft tissue following trauma especially the lip [3], if this is left undetected at the time of emergency treatment, it may remain undetected for a long period leading to infection and disfiguring fibrosis [4]. The present article reports a case of purulent discharging sinus from foreign body reaction in the upper lip due to lodged occult tooth for 25 years without patient awareness.

\section{Case Report}

A 40-year-old female patient, presented to the oral diagnosis clinic of Ahmadu Bello University Teaching Hospital Zaria, Kaduna state, Nigeria, with complaints of pain and purulent discharge from the upper lip of 5 days duration. The patient history revealed traumatic injury to the upper incisor tooth following traffic accident 25 years ago. The patient consulted a peripheral hospital after the accident where her upper lip was sutured and was told that she lost one of her teeth at the scene of the accident. Subsequently, patient did not receive any form of treatment or seek replacement for her missing tooth. For 25 years patient did not feel any discomfort or pain in her upper lip until 5 days prior to presentation when she felt pain and noticed purulent discharge from the upper lip. Clinical examination revealed swelling on the upper lip close to the midline with a discharging sinus (Figure 1). On palpation a hard mass was felt in the upper lip. Intraoral examination showed obliteration of the sulcus in the anterior maxillary segment with missing 21. Extra-oral radiographs showed a radiopaque structure similar to a tooth displaced into the facial soft tissue. (Figure $2 \& 3$ ).

Based on the patient's history, clinical examination and radiographic findings, the present case was diagnosed as embedded tooth in the upper lip following trauma with a discharging sinus. The diagnosis and treatment plan were explained to the patient and patient consented to treatment. Following local anaesthesia administration to the patient an incision was made on the upper lip to expose the tooth. The tooth was removed completely and sulcoplasty was done (Figure 4), followed by suturing with 3-0 


\section{Advances in Dentistry \& Oral Health}

Vicryl. The procedure was well tolerated by the patient and it was uneventful. Examination of the extracted foreign body confirmed that it was a tooth (Figure 5) that was embedded and undetected in the upper lip for 25 years, the root was also dilacerated, and the tooth was later discarded. The patient was reviewed regularly, and healing was uneventful. Follow up extraoral radiographs were taken Figure 6 \& 7 and revealed no tooth like structure. Patient is been planned for a removable partial denture for her missing 21 .

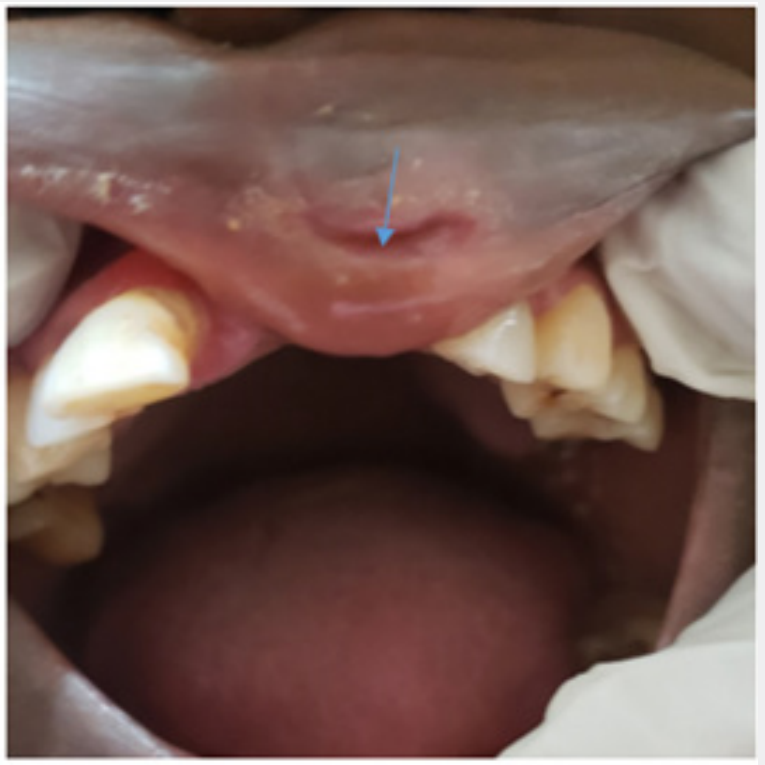

Figure 1: Clinical photograph showing patient's upper lip with the sinus, missing 21 and obliteration of the buccal sulcus in the anterior maxillary region.

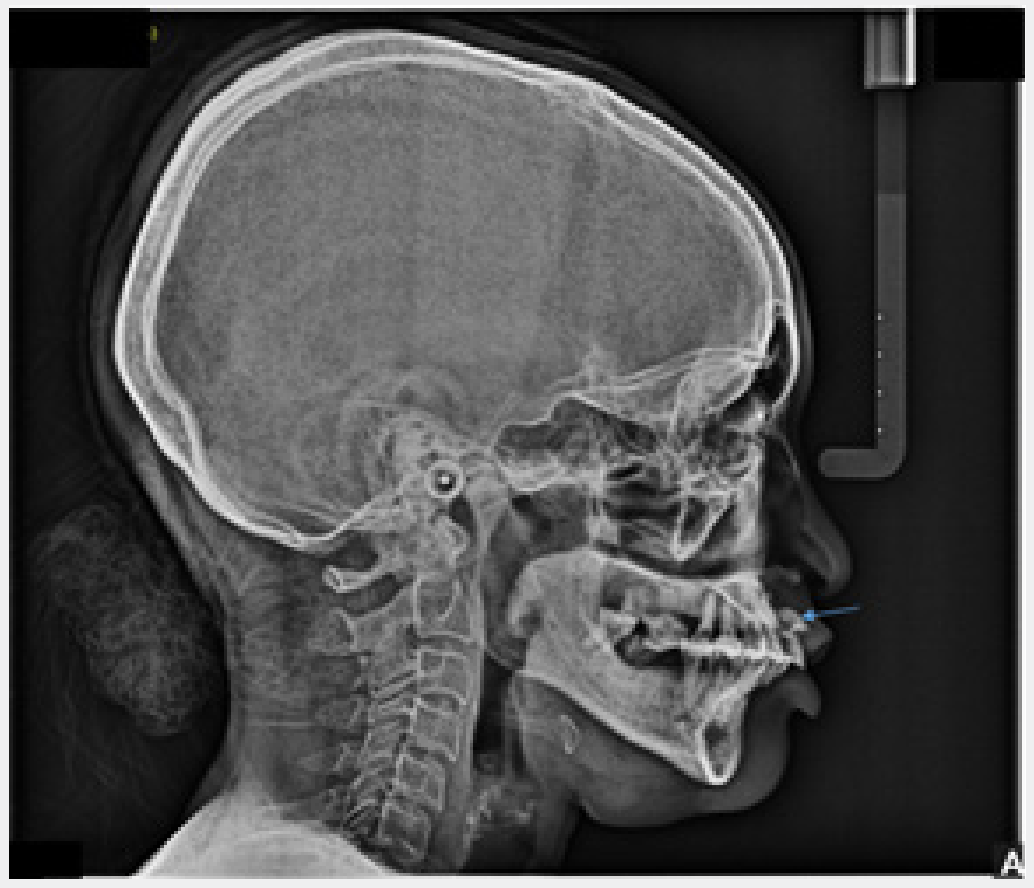

Figure 2: Tooth like structure seen in upper lip in the preoperative Cephalograph. 


\section{Advances in Dentistry \& Oral Health}

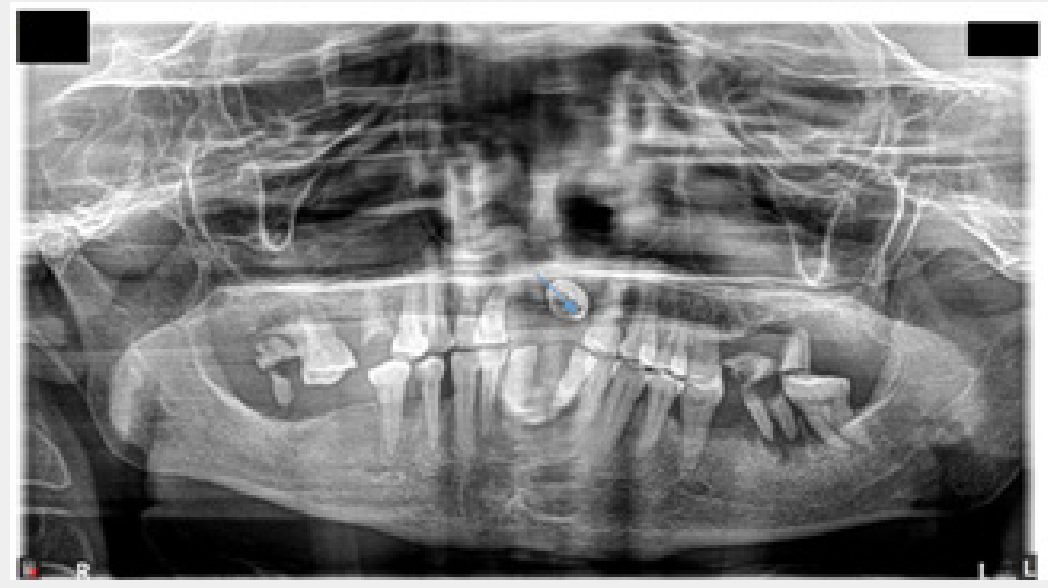

Figure 3: Tooth like structure seen in the preoperative Panoramic radiograph.

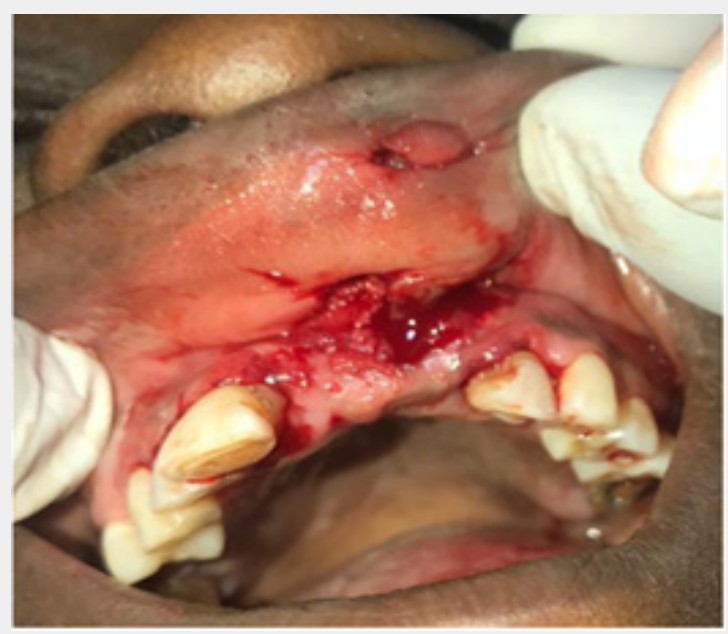

Figure 4: Clinical photograph showing patient's mouth following tooth removal and sulcoplasty.

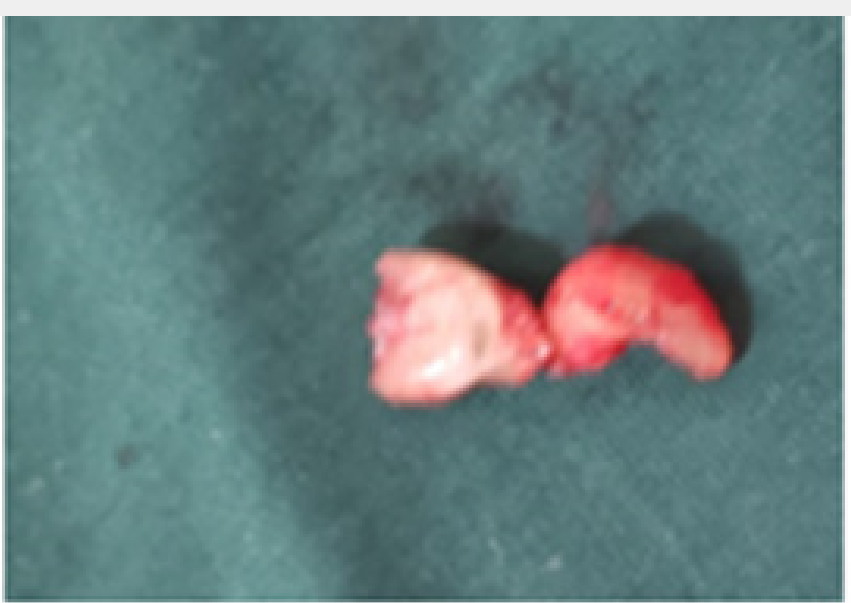

Figure 5: Extracted tooth. 


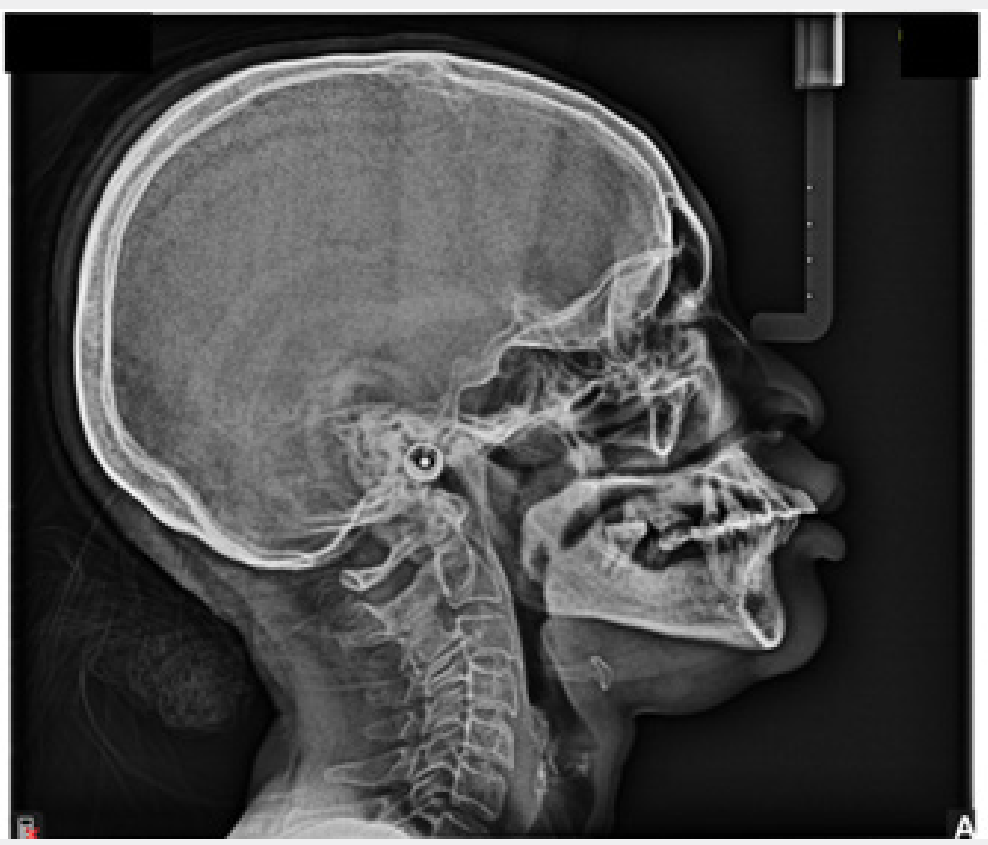

Figure 6: Postoperative Cephalograph.

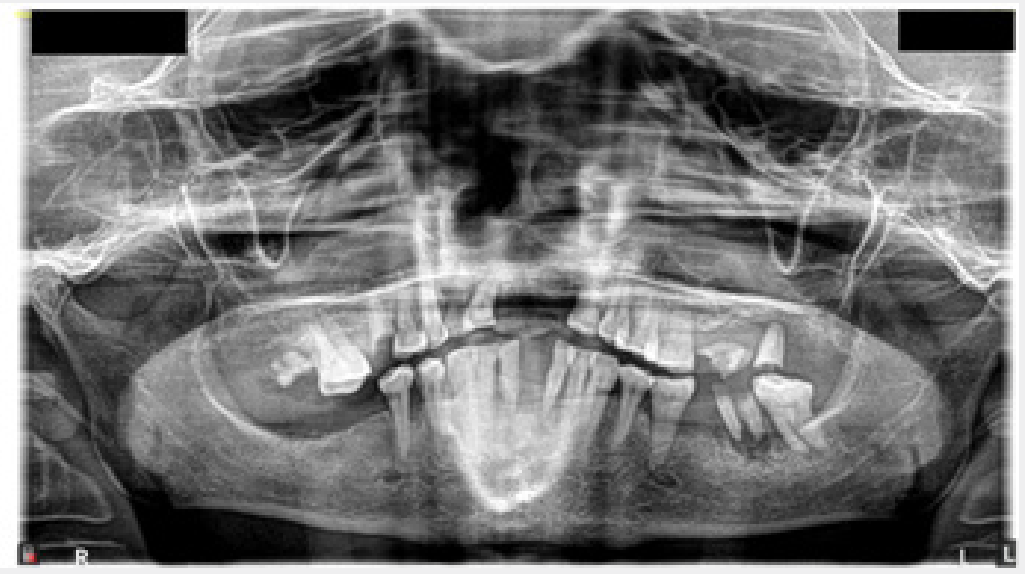

Figure 7: Postoperative Panoramic radiograph

\section{Discussion}

Trauma to the upper anterior teeth are most commonly encountered in the first decade of life, with fall being the most frequent etiology next to traffic accident [5]. Studies have shown that dental trauma is associated with soft tissue laceration and subsequent tooth/ tooth fragment embedment in the perioral soft tissue [2,3]. The lower lip was the most common site where the upper incisor tooth is embedded following trauma $[2,3,6]$. However, Kalra et al. [7], Cubuku et al. [8] \& Agarwal et al. [9] reported cases with tooth fragment embedded in the upper lip [7-9]. Also, Hill et al and McDonnell reported cases of tooth fragment embedded in the tongue [10,11]. Eruption of embedded undetected tooth from soft tissue have been reported [12] however, if the tooth does not erupt and remain within the soft tissue, persistence chronic inflammation with pus discharge and fibrosis may occur [2]. In the present case report, a tooth was embedded in the upper lip for 25 years, leading to fibrosis of the upper lip, pus discharge and obliteration of the maxillary anterior buccal sulcus. Clinically it may be difficult to detect tooth/ tooth fragment embedded in facial soft tissue. Use of radiograph to detect tooth/ 
tooth fragment in perioral soft tissue can help make a diagnosis $[8,9,13]$. In this case, radiographs helped in making the diagnosis. Once an embedded tooth is diagnosed on radiograph, complete removal is important. In this case, neither the patient nor the parents attempted to find the missing tooth following trauma at the site of the incident. Also, the medical practitioner who treated the patient did not evaluate the possibility of the missing tooth to be embedded in the upper lip during treatment. In the present case, following retrieval of the embedded tooth from the upper lip, the tooth was discarded because the root was dilacerated. Options for replacement for missing tooth was discussed with patient and she opted for a removal partial denture.

\section{Conclusion}

In conclusion, this paper emphases the need for a comprehensive physical and radiographic evaluation of patient with facial trauma especially in cases of dentoalveolar fracture with soft tissue laceration, even if the soft tissue has been sutured by another medical professional during emergency care. There is also a need for collaboration between medical practitioner and dentist for improved outcome in patient with facial trauma.

\section{References}

1. Cortes M, Marcenes W, Shelham A (2002) Impact of traumatic injuries on the permanent teeth on the oral health- related quality of life in 12 to 14-year old children. Community Dent Oral Epidemiol 30(3): 193198.

2. Nagaveni NB, Umashankara K (2014) Tooth fragment embedded in the lower lip for 10 months following dentoalveolar trauma: A case report with literature review. Burn trauma 2(3): 141-145.
3. Lauritano D, Petruzzi M, Sacco G, Campus G, Carinci F, et al. (2012) Dental fragment embedded in the lower lip after facial trauma: Brief review literature and report of a case. Dent Restor J 9(2): S237-241.

4. Wadkar M, Dhusia HK, Narkhede P (1986) Foreign body in the lip: Acase report. J Indian Dent Assoc 58:147-148.

5. (2010) American Academy of Pediatric Dentistry. Guideline on Management of Acute Dental Trauma.

6. Da Silva A, de Moraes M, Bastos E, Moreira RW (2005) Tooth fragment embedded in the in the lower lip after dental trauma: case report. Traumatology (Tallahass Fla) 21(2): 115-120.

7. Kalra N, Aggarwal A (1997) Traumatically embedded deciduous tooth in the upper lip of a six-year-old child. J Indian Soc Pedod Prev Dent 15: 76-77.

8. Cubukcu C, Aydin C, Ozbek S, Kahveci R (2011) Delayed removal of a primary incisor embedded in the upper lip after dental trauma: A case report about the importance of soft tissue examination. Dent Traumatol 27(4): 314-317.

9. Agarwal A, Rehani U, Rana N, Gambhir N (2013) Tooth fragment embedded in the upper lip after dental trauma: A case report presenting an immediate diagnostic approach and complete rehabilitation. J Indian Soc Pedod Prev Dent 31(3): 52-55.

10. Hill F, Picton JF (1981) Fractured incisor fragment in the tongue: A case report. Pediatr Dent 3(4): 337-338.

11. McDonnell DG, McKiernan EX (1986) Broken tooth fragments embedded in a tongue: A case report. Br J Oral Maxillofac Surg 24(6): 464-466.

12. Rao D, Hedge S (2006) Spontaneous eruption of an occult incisor fragment from the lip after eight months: Report of a case. J Clin Pediatr Dent 30(3): 195-197.

13. Altundasar E, Demiralp B (2013) The importance of soft tissue examination in post-traumatic decision-making. Aust Endod J 39(1): 35-38.

\section{Your next submission with Juniper Publishers} will reach you the below assets

- Quality Editorial service

- Swift Peer Review

- Reprints availability

- E-prints Service

- Manuscript Podcast for convenient understanding

- Global attainment for your research

- Manuscript accessibility in different formats

( Pdf, E-pub, Full Text, Audio)

- Unceasing customer service

Track the below URL for one-step submission https://juniperpublishers.com/online-submission.php 